\title{
The Association Between Environmental Strategies and Sustainability Performance in the Context of Environmental Management Accounting
}

\author{
Çevresel Yönetim Muhasebesi Bağlamında Çevresel Stratejiler ve \\ Sürdürülebilirlik Performansı İlişkisi
}

Metin UYAR ${ }^{1}$

https://orcid.org/0000-0002-9773-9340

\begin{abstract}
The study aims to explain the relationship between environmental strategies and sustainability performance in the context of sustainability accounting. The research addresses why and how environmental strategies affect sustainability performance through accounting information focusing on environmental priorities and modeling the transformation process. The hypotheses were tested using the partial least squares method and additional analyzes were used for further details. The findings show that environmental strategies have a positive relationship with sustainability performance and that the proposed transformation model has sufficient goodness fit statistics. It has been found that the positive impact of strategies on sustainable development is increased through the data generated by the environmental accounting system. This study demonstrates that environmental strategies are associated with sustainability performance, which is necessary for the improvement of corporate performance. In addition, the study shows significant impacts on management processes by demonstrating the necessity and potential of environmental accounting to improve sustainable development
\end{abstract}

Keywords: Sustainability performance, environmental strategies, environmental management accounting, accounting approach, partial least squares

\section{Introduction}

The contraction in balance sheet items, increases in production costs and business risk take the interest of firms in sustainable development. Sustainability is

\section{ÖZET}

Çalışma, sürdürülebilirlik muhasebesi bağlamında çevresel stratejiler ile sürdürülebilirlik performansı arasındaki ilişkiyi açıklamayı amaçlamaktadır. Araştırma, çevresel önceliklere odaklanan muhasebe bilgileri ve dönüşüm sürecinin modellenmesi yoluyla çevresel stratejilerin sürdürülebilirlik performansını neden ve nasıl etkilediğinden bahsetmektedir. Hipotezler kısmi en küçük kareler yöntemi kullanılarak test edildi ve daha fazla ayrıntı için ek analizler kullanıldı. Bulgular çevresel stratejilerin sürdürülebilirlik performansı ile pozitif bir ilişkiye sahip olduğunu ve önerilen dönüşüm modelinin yeterli iyilik uyum istatistiklerine sahip olduğunu göstermektedir. Çevresel muhasebe sisteminin ürettiği verilerle stratejilerin sürdürülebilir kalkınma üzerindeki olumlu etkisinin arttığı tespit edilmiştir. Bu çalışma, çevresel stratejilerin kurumsal performansın iyileştirilmesi için gerekli olan sürdürülebilirlik performansı ile ilişkili olduğunu göstermektedir. Ayrıca, çalışma sürdürülebilir kalkınmayı iyileştirmek için çevre muhasebesinin gerekliliğini ve potansiyelini göstererek yönetim süreçleri üzerinde önemli etkiler göstermektedir.

Anahtar kelimeler: Sürdürülebilirlik Performansı, çevresel stratejiler, çevresel yönetim muhasebesi, muhasebe yaklaşımı, kısmı en küçük kareler 
(Spence and Rinaldi, 2014). Lewis and Harvey (2001) emphasize that the uncertainty in the natural environment is a powerful factor affecting company strategies and accounting practices and their sustainability. Environmental sensitivity increases the need for a more transparent and informative structure of internal and external stakeholders about the environmental impacts of organizational activities. Social pressure leads to managers balancing sustainability and environmental responsibility (Labuschagne et al., 2005, Maas et al., 2016). Environmental awareness and environmental costs for stakeholder-driven enterprises can also bring about several opportunities and economic benefits. Especially the sensitivity shown for environmental sustainability brings with it economic benefits such as firms' cost reduction, increased profit rates and technological advantages (Klassen and McLaughlin, 1996, Russo and Fouts, 1997). Fiksel et al. (1999) state that adopting sustainability principles for governance will increase firms' capacity to create economic value and reduce the harm to the natural environment. Elkington (1998) addresses that one of the fundamental paradigms of the twenty-first century for businesses is showing sensitivity to environmental problems. Firms use sustainable environmental strategies and environmental management accounting to maintain a balance between organizational performance and environmental responsibility (Wagner and Schaltegger, 2003; Gunarathne and Lee, 2015). This relationship requires the adoption and implementation of environmental strategies and classical management strategies. In this context, environmental strategies are one of the main factors in the sustainability performance of the enterprises at the targeted level.

Larrinaga-Gonzalez and Bebbington (2001) underline that the accounting information must be integrated into environmental strategies. Especially environmental strategies that include the detailed accounting knowledge in the perspective of a natural resource-based view (NRBV) is one of the main drivers of business success and sustainability (Hart, 1995; Russo and Fouts, 1997, Clemens and Bakstran, 2010). In this direction, environmental strategies are the main determinants in the development of business performance by managing resources more accurately (Solovida and Latan, 2017). Well-organized management accounting knowledge within the enterprise is needed to ensure that environmental strategies have the desired effect on sustainability performance. In this context, sustainability accounting plays a critical role.

There are two basic approaches to addressing the relationship between accounting and sustainability (Passetti et al., 2014). "The critical perspective" argues that sustainability is possible by using accounting data toward business interests. "The managerial perspective" emphasizes that sustainability accounting is an inevitable factor for business performance with a more pragmatic approach (Burritt, 2012). Epstein and Buhovac (2010) state that sustainability issues should be included in planning decisions, capital budgeting and performance measurement, so that environmental and social issues can be integrated into key decisions. Environmental management accounting is accepted as the major part of sustainability accounting (Hyršlová and Hájek, 2006; Debnath and Accountants, 2012; Figge et al., 2002). As emphasized by Chenhall (2003) and Ismail and Isa (2011), a well-designed and efficient accounting system helps managers improve their firm performance by making accurate and rational decisions. In this context, the contribution to sustainability performance will be positive.

This study aims to respond the question; "what is the relationship between environmental strategies and sustainability performance in the frame of environmental management accounting?" While many studies examining the relationship between accounting and sustainability issues address dimensions such as institutional transparency, and corporate governance (Mákelá, 2017; Maas et al., 2016; Lodhia and Hess, 2014), this study considers that the social, environmental and economic dimensions of sustainability should also be assessed. This study emphasizes the paucity of research on environmental management accounting, environmental strategies, and sustainability performance, and aims to fill that gap by providing evidence using structural equation modeling on this relationship. The structure of the remaining paper is organized as follows. In the next section presents a conceptual framework and the theoretical background. Section 3 represents hypotheses and the structural model of the study. Section 4 sets out the research method and variable measurement are presented, followed by an analysis of the results. Section 5 presents a summary of the research, identifies limitations, and research issues for future studies. 


\section{Conceptual Framework}

\subsection{The Environmental Management Accounting}

The limited contribution of traditional accounting practices at the point of sustainability has made its role debatable for sustainability performance (Maunders and Burritt, 1991). Hines (1991) discussed that the accounting should assume a new role outside the existing functions. There is an increase in the analysis of the role of environmental accounting in the provision of sustainable organizations (Brundtland, 1987; Christ and Burritt, 2013; Schaltegger and Csutora, 2012). Environmental management accounting and reporting are asserted by Gray and Milne (2002) to address a mandatory task because of the need to emphasize the entity concept and focus on ecosystems and their features, thresholds and total consequences. The environmental management accounting places a special position on environmental performance and extended performance assessed by physical, qualitative or non-financial criteria in sustainability (Yongvanich and Guthrie, 2006). Environment-oriented management accounting structure provides a more accurate assessment of the economic, environmental and social activities of the organization (Elkington, 1998). In this context, environmental management accounting has a focus on integrating social, environmental and economic facets of organizational processes (Lamberton, 2005; Thomson, 2007). Specifically, environmental management accounting has been introduced as a means, by which the business community can manage its environmental and related economic performance more (Christ and Burritt, 2013). Some authors see environmental initiatives and practices as a tool, which helps organizations gain a competitive advantage and improve overall performance (Cullen and Whelan, 2006, Claver-Cortes et al., 2007). However, insufficient relevant environmental information can prevent corporate decision makers from making rational decisions (Mokhtar et al., 2016). By preparing and providing data related to the physical and financial aspects of environmental performance, some argue that accounting will provide information that can be used by the corporate management to test the chances for economic and environmental improvement (Gale, 2006).

Thomson (2007), and Beblington and Larrinaga (2014) discussed the relationship between environ- mental accounting and risk management. Because industrial development also brings environmental risks. Risk management is an activity that protects the environment and the businesses by maximizing predictability, with little or no predictability of unforeseen events in terms of risk. To manage risks, companies must use different tools for sustainability performance. In this direction, Gond et al. (2017) show that information-centric environmental management accounting practices can reduce strategic uncertainties and risks in the sustainability perspective. Many aspects of sustainability accounting have been examined. Henri and Journeault (2010) presented the notion of "eco-control" as the application of financial and strategic control methods to environmental management. While Roth (2008) examines environmental budgeting and planning concepts.

Another important issue related to environmental accounting is in compliance with the sustainability objectives of accounting technologies. Enterprise resource planning software and applications are helping at this point. Accounting technologies should be adopted and oriented by the companies with the awareness that the targets are environmental protection and reduction of environmental impacts (Burritt, 2012; Spence et al., 2010 Brown, 2009). Sustainability is governed extensively to ensure the control and protection of natural resources and financial outcomes at the desired level (Tregidga et al., 2014). The environmental management accounting is considered as a mechanism for sustainability and contribute to environmental protection. (Tinker and Gray, 2003). However, the adaptation of environmental accounting practices to enterprises often depends on legal obligations.

There are also studies that indicate that businesses do not want to disclose their sustainability performances and therefore are distracted by environmental management accounting (Owen, 2008). Factors such as the inability of companies to deal with the conservation of natural resources, the cost of most schemes, and economic crises negatively affect the desired level of adaptation and effectiveness of environmental management accounting. Studies of Australia (Wilmshurts and Frost, 2001), Germany (Burritt et al., 2011), Italy (Comoglio and Botta, 2012) have shown that environmental management accounting is moderately important and adapted for businesses. Some studies also point to the existence of a balance between economic activity and protection of the environment (Figge and Hanh, 2013). 


\subsection{Environmental Strategies}

"A corporate environmental strategy can be described as a set of initiatives that mitigate the impact of a firm 's activities on the natural environment through products, processes and policies such as reducing energy consumption and waste generation, using ecological sustainable resources, and implementing an environmental management system" (Bansal and Roth, 2000). Increasing environmental, economic and social uncertainties have forced businesses to choose and implement proactive strategies (Aragon-Correa and Rubio-Lopez 2007; Eiadat et al. 2008; Nidumolu et al., 2009; Sharma 2014, Alt et al. 2015, Bhupendra and Sangle, 2015). All organizations require having an environmental strategy and sustainable accounting information systems (Latan et al., 2018). For instance, firms may implement new technologies that reduce material costs and prevent air pollution, and they may adopt environmental management systems (Eiadat et al. 2008). Efforts to explain how the effective environmental strategy will be used show that the strategy will provide a competitive advantage if used correctly (Hart, 1995, Hart and Dowell, 2011, Klassen and Whybark, 1999, Journeault, 2016). The economic, social and environmental performance of firms using proactive strategies reaches the targeted level in this framework (Rodrigue et al., 2013).

The classification and naming of environmental strategies can be done in different ways. Environmental strategies are: (i) Environmental technology using strategy, (ii) Energy saving strategy, (iii) Product development and marketing strategy (environmentally friendly), (iv)Packaging strategy (v) Recycling strategy (Parker, 1997). One or multiple strategies can be used in the same operational cycle. At this point, the management's vision and environmental commitment to stand out for strategic options.

\subsection{Sustainability Performance}

The likelihood of damage to the environment by operations of companies is causing both internal stakeholders and external stakeholders to worry. Increased transparency helps to illuminate society through financial reporting (Labuschagne et al., 2005; Maas et al., 2016; Adams et al. 2014, Roca and Searcy 2012, Morioka and Carvalho 2014, Silvestre et al. 2015). Sustainable development depends not only on economic success and environmental sensitivity but also on social influences. Studies show that the need for sustainable development is high in the belief and that stakeholders force managements to provide better quality information (Bebbington and Gray, 2001, Wilmshurst and Frost, 2001; Ball, 2005; Albelda, 2011; De Villiers and Van Staden, 2006). "Sustainable development and performance have three dimensions: economic viability, social responsibility, and environmental responsibility" (Elkington, 2004).

The work of sustainability performance for businesses reveals that organizational performance is influenced by sustainable development (Morioka and Carvalho, 2014 Luzzini et al., 2015; Delai and Takahashi, 2011; Kocmanová et al., 2016; Abdul-Rashid et al., 2017). Schrettle et al. (2014) define that many cultural, administrative, social factors influence the permanence of organizations. A knowledge-based organization is more likely to achieve sustainable development and performance. The influences of legal and regulatory regimes, along with market and competitive pressures are driving this direction (Linnenluecke and Griffiths, 2013), the current demands on natural resource use and environmental issues (Wu and Pagel, 2011). The green product demand of society is another factor that drives companies to think more about environmental innovation and sustainability. This change, on the one hand, transforms the concept of sustainability into a more popular phenomenon, which incorporates environmental technologies and additional environmental costs into the daily lives of enterprises (Etzion, 2007). There are many obstacles that prevent sustainability performance from being desired. Whether human resources are inadequate, the presence of obstacles stemming from financial and organizational architecture, especially small and medium-size making it difficult for businesses to achieve sustainable performance. Increasing raw material costs on a global scale, depending on changes in exchange rates and interest policies, make green production difficult or cause firms to postpone environmental investments (Lozano, 2015; Silvestre et al., 2016).

\section{Hypotheses and Structural Model}

\subsection{Environmental Strategies and Sustainability Performance}

Henri and Journeault (2010) argue that the strategic planning framework has a direct impact on sustainable development and performance. A company with environmental strategies is more likely to achieve sustainability goals than a company that does not have environmental strategies. Strategies will be more decisive, especially at the point of environmental performance 
and sustainability (Wagner and Schaltegger, 2004). Proactive strategically managed enterprises make a difference and reach their goals by going beyond regulations at the point of environmental, economic and social sustainability (Rodrigue et al., 2013). Most companies have adopted targets and activities related to environmental strategies, such as participation in eco-efficiency, pollution prevention and social responsibility projects (Hart and Dowell, 2011). Strategies such as product development, energy saving, clean technology usage, and the activities and targets mentioned, have significant effects on performance.

While reducing operational costs and achieving energy efficiency using an energy conservation strategy, entering a new market using strategies for developing environment-friendly products, technologies and services can improve sustainability performance because of operating performance. Environmental performance is a component of total quality management and can contribute to cost-effectiveness, waste management, and increased income. It creates a safer and responsible ecosystem for employees and stakeholders and is a positive reflection of the sustainability performance of environmental strategies. Environmental strategies, such as the recycling strategy or clean technology strategy, can lead to long-term businesses to focus on the internal environment, and focus more on environmental indicators.

Using environmental strategies are related to internal and external strategies. For example, insufficient product and service quality effect strategic options with internal and external factors (Arjali's and Mundy, 2013; Bansal, 2005), such as the waste of resources, and the lack of alignment of strategies with worker safety and health (Haugh and Talwar, 2010). They can also work with specific tasks and tasks within the organization. This effect can increase both environmental performance and economic and non-economic performance. In the light of arguments, which has been discussed above, hypothesis 1 is constructed as follows:

$\mathrm{H} 1$. There is a positive relationship between environmental strategies and sustainability performance.

\subsection{Environmental Strategies and Environmental Management Accounting}

The impact of environmental problems on customer and market demands increases the need for environmental accounting knowledge (Hopwood, 2009; Bouten and Hoozée, 2013). Environmental costs and benefits are increasingly affecting management strategies. Shields and Boer (1997) state that for the United States, environmental costs have reached 22 percent of total operating costs. Accurate calculation and control of costs, therefore, reveal the importance of environmental management accounting. Accurate classification, summarization, and reporting of increased environmental data also increase the significance of environmental accounting and the importance of decision-making processes. Strategy development and implementation have both influenced and improved environmental management accounting (Perego and Hartmann, 2009; Herbohn, 2005). This development manifests itself in environmental cost reporting systems (Alewine, 2010) and investment decisions (Deegan, 2002). In this context, strategic environmental objectives should also include indicators of investment opportunities of companies. Sustainability accounting is thus one of the main decision support mechanisms of company strategies (Dascalu et al., 2010, Pondeville et al., 2013; Journeault, 2016).

Environmental management accounting, which is a major part of sustainability accounting can be considered as a contingent of environmental strategies (Parker, 1997). Christ and Burritt (2013) point out that accounting data has a valuable role in the development of environmental strategies. This points to a set of standard processes and practices that maximize the effectiveness of environmental management. Pérez et al. (2007) stated that there are two types of intangible asset elements considered in the continuous improvement process: (1) integration of environmental processes and issues into strategic planning processes; (2) the use of management accounting practices. In a more comprehensive and synergistic structure, environmental management accounting will generate intangible assets that will enhance the environmental performance and sustainability performance of organizations.

Environmental strategies transform management accounting into a structure that will reduce environmental uncertainty and provide information. This lead to the relationship between environmental strategy and sustainability accounting. The hypothesis 2 is constructed as follows:

$\mathrm{H} 2$. There is a positive association between environmental strategies and environmental management accounting. 


\subsection{Environmental Management Accounting and Sustainability Performance}

Companies are aiming to increase their environmental and economic performance by using accounting data. Larrinaga et al. (2001) have demonstrated that some Spanish companies use their accounting knowledge to increase their environmental performance, thus emphasizing that the perceptions of society have reached a positive level. Where does sustainability account for this benefit? The root of this benefit is the inability to prepare and analyze data on the sustainability performance of traditional accounting. Likewise, relevant past studies present this inadequacy (Mathews, 1997, Schaltegger and Burritt, 2000). It is necessary to pay attention to the components of the environmental management accountant to find the right answer to this question.

Environmental Accounting provides physical and financial data flow to decision makers and stakeholders for assessing and enhancing both environmental and economic performance. Strong and accurate information flow leads to the transformation of business resources into optimal investments and decisions. Thus, the sustainability performances of enterprises increase. In this respect, environmental accounting contributes to both the reduction of environmental costs and the planning of the future (Schaltegger and Burritt, 2000; Hansen and Mowen, 2005). Moreover, sustainability accounting offers a monetary viewpoint in the preparation and analysis of raw materials and energy use reports, reducing resource waste and caring for energy efficiency (Bartolomeo et al., 2000; IFAC, 2005).
Epstein and Widener (2011) state that sustainability-related information will contribute to the development of energy technologies and to protecting wildlife. Adams and McNicholas (2007) emphasize that environmental accounting reveals a more appropriate perspective to analyze the performance and policies of the corporations. The most important impact of the sustainability accounting is to integrate sustainability issues into strategic planning and assessment of environmental and social performance indicators.

In several studies showing the effects of environmental management accounting use and adaptation in the realization of business objectives, management opinion as a common view suggests that it paves the way for control and evaluation (Derchi et al., 2015; Schaltegger and Burritt, 2000). Bouten and Hoozée (2013) addressed the interaction of environmental accounting and reporting in the natural cycle deterioration process. They express that environmental accounting offers an important opportunity to achieve sustainability. In the light of these arguments, the hypothesis 3 and the hypothesis 4 were constructed as follows:

$\mathrm{H} 3$. There is a positive association between environmental management accounting and sustainability performance

H4. Environmental strategies and environmental management accounting have a joint effect on sustainability performance positively

The research model is shown in Figure 1.

\section{Research Methodology and Implementation}

\subsection{Survey Design and Data Collection}

The study evaluates the manufacturing companies (some of them have ISO 14001-certificate) which are more related to the environmental impacts of business operations than other companies. However, due to a time limit, availability and limited research budget used in this study, manufacturing companies having a minimum of 20 employees and operating in Istanbul were taken as the sample. A questionnaire prepared for the managers and accounting staff in the accounting departments of the companies was sent via e-mail (see, Annex 1). Emails have compiled from the web pages of

Figure 1: The Structural Model 
businesses. The number of companies sent e-mail is approximately 1200 and 126 questionnaires are suitable for data analysis. The collection phase has gone approximately 6 months (from May 2018 to November 2018). According to the sectors, 49 of the companies are from machinery/metal and metal goods sector, 26 from the textile and clothing sector, 28 from the electronic and electrical sector and 23 from chemical products sector. According to the number of employees, the number of firms with 20-40 personnel is 49 , the number of firms with 41-60 personnel is 35 , the number of firms with 61-80 personnel is 17 , the number of firms with $81-100$ personnel is 14 , the number of firms is 11 . The respondents to the questionnaire are 108 accounting staff and 18 managers. Average profession experience of participants are 5.3 years.

\subsection{Measuring instrument, validity, and reliability}

The measuring tool used to determine variables comprises three parts. The first part explains the purpose and objectives of the study. The second part aims to determine the demographics of the participants. In the third part, there are questions about the basic variables of the research. Scales were used to measure the factors and variables based on previous studies. However, a new environmental strategies scale has been developed based on the environmental strategies set out in Parker (1997). Items in the scales were prepared using the five-point Likert scale. Environmental strategy, environmental management accounting, and sustainability performance are the variables to be investigated. Environmental strategies scale consists of 15 items. These items are designed to measure clean technology usage strategy, energy conservation strategy, environmentally friendly product development and marketing strategy, environmental packaging strategy and recycling strategy. Thirty-one items from the survey in the study of Caiado (2018) were used to measure the sustainability performance. Environmental Management Accounting has used 12 items from Ferreira et al. (2010). Factor and reliability analyzes were performed to determine the reliability of the scales used for data acquisition. In this context, KMO analysis was conducted and tested by creating a factor analysis model. Depending on the analysis, the factor loadings and reliability of the factored design (Cronbach Alpha) were reached presented in Table 1. The question roots have been answered by the participants with "Please mark the closest option to you, considering your past work by your company" sentence.

Table 1: Factor Analysis and Reliability

\begin{tabular}{|c|c|c|}
\hline & $\begin{array}{l}\text { Factor } \\
\text { Loads }\end{array}$ & Cronbach a \\
\hline \multicolumn{3}{|l|}{ Environmental Strategies } \\
\hline 1) Clean Technology Usage Strategy (AVE $=0.662, \mathrm{KMO}=0.730)$ & & 0.780 \\
\hline $\begin{array}{l}\text { Our business is intended to use practices and technologies that are less harmful to the } \\
\text { environment in their operational processes }\end{array}$ & 0.797 & \\
\hline Operational processes use technologies with a low risk of harm to the environment & 0.773 & \\
\hline Carbon emissions and waste generation are the priorities of our use of low technology. & 0.785 & \\
\hline 2) Energy Conservation Strategy $(\mathrm{AVE}=0.717 ; \mathrm{KMO}=0.754)$ & & 0.777 \\
\hline Reduction of energy consumption in operational processes is aimed to operate. & 0.716 & \\
\hline Energy alternatives towards environmental protection are used in our preference. & 0.805 & \\
\hline Reducing energy costs is ahead of our company. & 0.760 & \\
\hline $\begin{array}{l}\text { 3) Environmentally Friendly Product Development and Marketing Strategy (AVE }=0.781 \text {; } \\
\mathrm{KMO}=0.788 \text { ) }\end{array}$ & & 0.742 \\
\hline $\begin{array}{l}\text { It is our primary purpose to operate environmental awareness in product development and } \\
\text { marketing. }\end{array}$ & 0.757 & \\
\hline We design our products to minimize damage to the environment. & 0.724 & \\
\hline $\begin{array}{l}\text { In the production of our products, it is our priority to use less harmful raw materials and } \\
\text { components. }\end{array}$ & 0.665 & \\
\hline 4) Environmental Packaging Strategy ( $\mathrm{AVE}=0.549 ; \mathrm{KMO}=0.620)$ & & 0.704 \\
\hline $\begin{array}{l}\text { In the packaging of our products, we use reminders and signs to protect the environment } \\
\text { and protect the environment. }\end{array}$ & 0.687 & \\
\hline Product packages are made from low-risk materials for environmental damage. & 0.680 & \\
\hline The product packaging is prepared from non-toxic materials. & 0.761 & \\
\hline
\end{tabular}


5) Recycling Strategy ( $\mathrm{AVE}=0.769 ; \mathrm{KMO}=0.818$ )

Our products are prepared from recyclable raw materials.

0.866

0.841

Recycling is a priority policy in the work of the enterprise.

0.853

Using organic and recyclable raw materials is the main objective of our company.

Environmental Management Accounting (AVE=0.814; KMO=0.881)

Identification of environment-related costs

0.774

Estimation of environment-related contingent liabilities

0.875

Classification of environment-related costs

0.820

Allocation of environment-related costs to production processes

0.819

Allocation of environment-related costs to products

0.862

Introduction or improvement to environment-related cost management

0.855

Creation and use of environment-related cost accounts

0.824

Development and use of environment-related key performance indicators

0.841

Product inventory analysis

0.851

Product impact analysis

0.767

Product improvement analysis

0.863

Product life cycle cost assessments

0.729

\section{Sustainability Performance}

1) Economical Sustainability ( $\mathrm{AVE}=0.652 ; \mathrm{KMO}=0.738$ )

Cost performance is improving positively.

0.804

Environmental and social performance has improved positively.

Quality management has been implemented successfully

Labour practice indicators were achieved at the targeted level.

Customer satisfaction is the targeted level

Corporate reputation is the targeted level.

It is suited to the objectives of the HUM capital development operator.

0.784

2) Social Sustainability (AVE=0.688; $\mathrm{KMO}=0.709$ )

Intra-firm collaborative capabilities suited to business goals

Employee satisfaction is targeted.

0.757

Supplier relations continued in line with business interests.

Environmental logistics policy is organized according to business objectives.

Social benefits have been completed to give the medical-legal environment at least a loss.

Balancing professional and family life has been emphasized by business management.

Representation and dialogue with employees have been held regularly.

Code of conduct is implemented in operation.

Corporate governance is the targeted level.

Support of social setting is suitable for the targets.

The sustainable working condition is provided to stakeholders in business management.

3) Environmental Sustainability (AVE=0.728; $\mathrm{KMO}=0.803$ )

Environmental protection has been considered in operational processes.

Green marketing applications have been made.

Environmental policy has been applied meticulously.

Energy conservation has achieved the targets.

Carbon footprint reduction is provided.

Reduction in the amount of energy used.

Reduction of air pollution is provided. 
Based on the results of $\mathrm{KMO}$, it was determined that environmental strategies comprise clean technology usage strategy, energy conservation strategy, environmentally friendly product development and marketing strategy, environmental packaging strategy and recycling strategy. Sustainability performance comes from the sub-dimensions of environmental sustainability, economic sustainability, and social sustainability. Environmental management accounting is considered as a single factor. The AVE values of each factor confirm the validity of the scale items. At Hair et al. (2006), the validity characteristics of the measurement models were evaluated with different indices. As understood from the table 2 . The factors used in the research are confirmed by the fit indices. The theoretical research model is a correct structure in terms of reliability and validity values and is suitable to be used structurally. According to the results of goodness fit index (GFI) and comparative fit index, the structural validity of each variable agrees with the reference values. This indices were found to be $\mathrm{GFI}=0.94$ and $\mathrm{CFI}=0.97$ for environmental strategies. For environmental management accounting, $\mathrm{GFI}=0.95$ and $\mathrm{CFI}=0.97$. The goodness indices for sustainability performance are $\mathrm{GFI}=0.96$ and $\mathrm{CFI}=0.98$.

\subsection{Hypothesis Testing and Findings}

Research data were compiled using AMOS (Analysis of Moment Structures) program and subjected to statistical analysis processes. First, the theoretical model of the research was tested, and the revised values were re-analyzed in line with the parameters. At this stage, the power of direct and indirect relationships between research variables has been revealed.

The correlation values indicate the existence of relationships between all variables. Figure 2 and Table 4 show the findings obtained based on the theoretical model of the study.

Table 2: The validity of the research model

\begin{tabular}{lcccc}
\hline \multicolumn{1}{c}{ Indexes } & $\begin{array}{c}\text { Reference } \\
\text { Value }\end{array}$ & $\begin{array}{c}\text { Environmental } \\
\text { Strategies }\end{array}$ & $\begin{array}{c}\text { Environmental Management } \\
\text { Accounting }\end{array}$ & $\begin{array}{c}\text { Sustainability } \\
\text { Performance }\end{array}$ \\
\hline $\mathrm{X}^{2} / \mathrm{df}$ & $<3.00$ & 0.19 & 2.00 & 1.59 \\
$\mathrm{GFI}$ & $>0.90$ & 0.94 & 0.95 & 0.96 \\
$\mathrm{CFI}$ & $>0.90$ & 0.97 & 0.97 & 0.98 \\
$\mathrm{RMSEA}$ & $<0.08$ & 0.02 & 0.03 & 0.05 \\
$\mathrm{RMR}$ & $<0.08$ & 0.04 & 0.05 & 0.05 \\
$\mathrm{NFI}$ & $\approx 1.00$ & 1.01 & 0.98 & 1.13 \\
\hline
\end{tabular}

X2/df, GFI: Goodness Fit Index, CFI: Comparative Fit Index, RMSEA: Root Mean Square Error of Approximation, RMR: Root Mean Square Residual, NFI: Normed Fit Index

Table 3: Discriminant Reliability and Correlations

\begin{tabular}{llllllc}
\hline Variable & Mean & SD & VAVE & EST & EMA & SUP \\
\hline Environmental Strategy & 4.038 & 0.017 & 0.844 & 1 & & \\
Environmental Management Accounting & 3.843 & 0.034 & 0.902 & $0.478^{* *}$ & 1 & $0.381^{* *}$ \\
Sustainability Performance & 3.909 & 0.011 & 0.860 & $0.395^{* *}$ & 1 \\
\hline
\end{tabular}

Note: The italic elements are the correlations between the research variables; EST: Environmental Strategy; SUP: Sustainability Performance; EMA: Environmental Management Accounting

Significance for ${ }^{*} p<0.01 \quad{ }^{* *} ; p<0.05 ; \quad{ }^{* *} p<0.10$ 


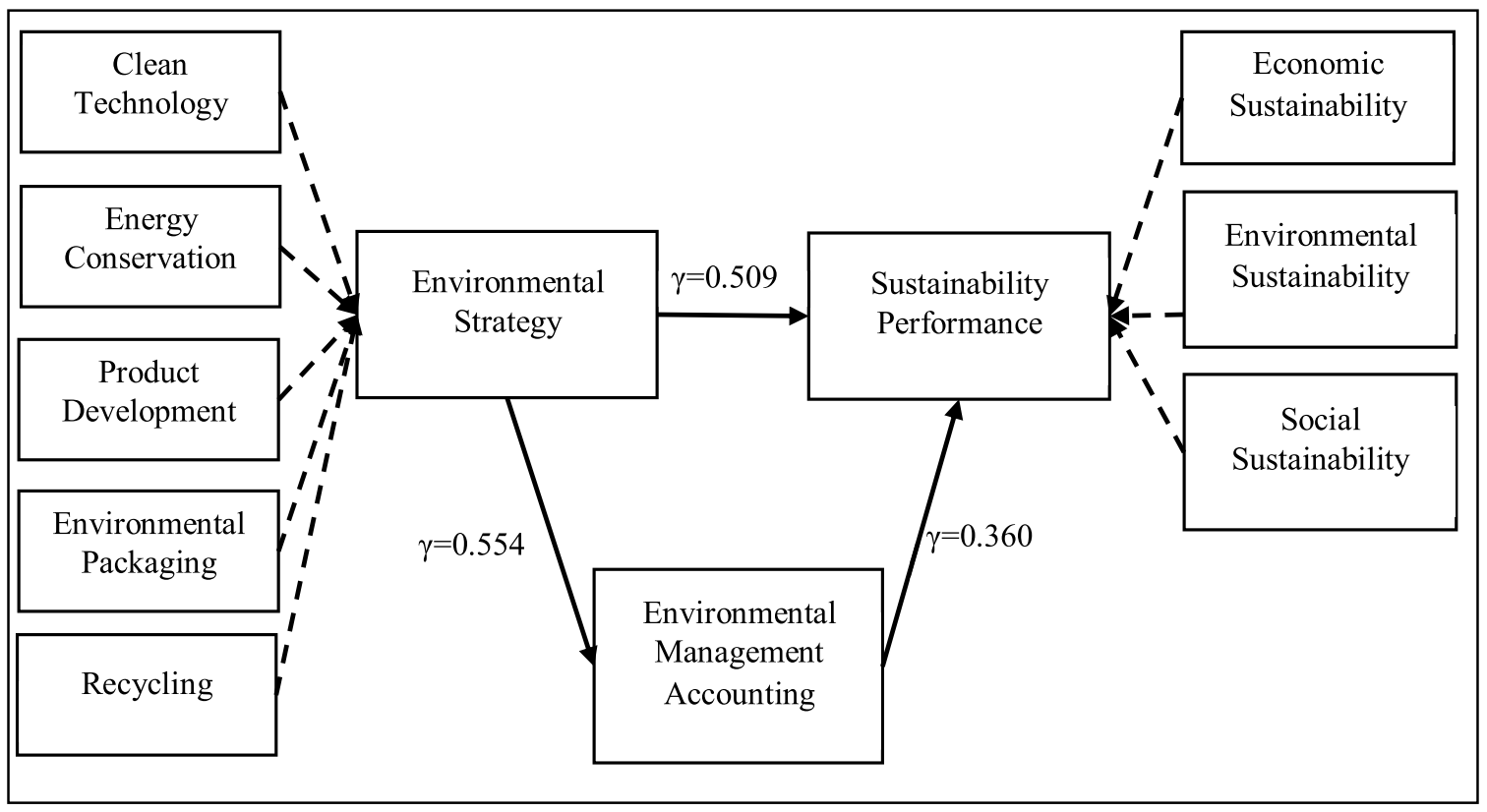

Figure 2: Tested Model

According to Figure 2, the environmental strategies implemented by businesses have a significant impact on sustainability performance in a positive and strong way $(\gamma=0.509$ and $p=0.000)$. The gamma $(\gamma)$ value shows it directly influences environmental sustainability performance. Every step that businesses take as an environmental strategy will help increase business sustainability performance.

According to Table 4, environmental strategies are found to have a variance value $\left(R^{2}=0.39\right)$ which gives rise to the dependent variable of sustainability performance. This shows a high impact for a single-factor model and indicates that environmental strategies are predictive of sustainability performance. Another important criterion for the analysis of the structural equation model is that the tested model is accepted correctly in the compliance indices. The compliance indices in Table 4 are acceptable values in terms of reference values $(\gamma=0.360$ and $p=0.000)$. Findings show that data produced by environmental management accounting have a positive impact on economic, environmental and social sustainability. The variance value $\left(R^{2}=0.30\right)$ between the relationship between environmental management accounting and sustainability performance. It is also confirmed that the goodness indexes of relevance are also meaningful with reference values and that the model is correct. When considered in terms of research design, it is understood from both the gamma coefficients and the variance values that the effect of the environmental strategy variable on the sustainability performance is higher than the effect of the environmental management accounting variable on the sustainability performance. The environmental strategy variable is understood from the test model $(\gamma=0.554$ and $p=0.000)$, which significantly affects the environmental management accounting variable. It is aimed to determine the common effect of two predictive variables, environmental strategy, and environmental management accounting dependent variables. As shown in Table 4, (Environmental Strategy $x$ Environmental Management Accounting) $\rightarrow$ (Sustainability Performance) was found statistically significant and positive $(\gamma=0.618$ and $p=0.000)$. If the effectivity of sustainability performance is variance $\left(R^{2}=0.59\right)$. The correctness of the test model was determined to confirm the model's compliance indices. After testing the research model, the direct effects of the sub-factors (sub-dimensions) forming the independent variables to the sub-dimensions of the dependent variable were examined. According to the findings in Table 5 , clean technology significantly affects economic sustainability, environmental sustainability, and social sustainability ( $\beta=0.135, \beta=0.166, \beta=0.150$ ). The clean technology strategy is making significant contributions to sustainability performance. However, the energy conservation strategy is significantly related to environmental sustainability performance and social sustainability performance. However, it does not significantly influence economic sustainability performance. Contrary to the theoretical model of environmental packaging strategy, it has significantly 
affected no sub-dimension of the sustainability performance variable. Product development strategy influences the economic sustainability. However, there was no acceptable activity on social and environmental sustainability. Recycling strategy provides a significant contribution to sustainability performance.

According to the findings in Table 5, there are no significant correlations between some sub-factors.
As a characteristic of structural equality models, it is necessary to revise the test models by revising them. In this context, it is correct that the weak test parameters are deducted from the model and the model is tested again. Thus, the correctness of the theoretical model and the increase in the explanatory power will be possible. The revised structural equation model and its detailed findings are shown in Figure 3 and Table 6.

Table 4: Test of the Research Model

\begin{tabular}{lcccccc}
\hline \multicolumn{1}{c}{ Paths } & \multicolumn{1}{c}{$\mathbf{R}^{\mathbf{2}}$ (\%) } & $\mathbf{p}$ & $\boldsymbol{X}^{\mathbf{2}}$ /df & RMSEA & GFI \\
\hline EST $\rightarrow$ SUP & 0.509 & 39 & $0.000^{*}$ & 2.07 & 0.02 & 0.95 \\
EMA $\rightarrow$ SUP & 0.360 & 30 & $0.000^{*}$ & 2.24 & 0.03 & 0.94 \\
EST $\rightarrow$ EMA & 0.554 & 51 & $0.000^{*}$ & 1.99 & 0.02 & 0.95 \\
EST $x$ EMA $\rightarrow$ SUP & 0.618 & 59 & $0.000^{*}$ & 1.68 & 0.02 & 0.96 \\
\hline
\end{tabular}

EST: Environmental Strategy; SUP: Sustainability Performance; EMA: Environmental Management Accounting

${ }^{*} \mathrm{p}<0.01 ;{ }^{* *} \mathrm{p}<0.05 ;{ }^{* * *} \mathrm{p}<0.10$

Table 5: Paths Between Sub-factors

\begin{tabular}{lllllll}
\hline & \multicolumn{2}{c}{$\begin{array}{c}\text { Economical } \\
\text { Sustainability }\end{array}$} & $\begin{array}{c}\text { Environmental } \\
\text { Sustainability }\end{array}$ & \multicolumn{2}{c}{ Social Sustainability } \\
\hline Clean Technology & $\beta$ & $p$ & $\beta$ & $p$ & $\beta$ & $p$ \\
Energy Conservation & $0.135^{* * *}$ & 0.028 & $0.166^{* *}$ & 0.022 & $0.150^{* *}$ & 0.023 \\
Product Development & 0.049 & 0.115 & $0.127^{* *}$ & 0.040 & $0.067^{* * *}$ & 0.092 \\
Env. Packaging & $0.112^{* *}$ & 0.043 & 0.030 & 0.251 & 0.061 & 0.135 \\
Recycling & 0.004 & 0.183 & 0.046 & 0.208 & 0.006 & 0.208 \\
Environmental Management Accounting & $0.142^{* *}$ & 0.025 & $0.188^{* *}$ & 0.014 & $0.088^{* * *}$ & 0.094 \\
\hline
\end{tabular}

${ }^{*} p<0.01 ;{ }^{* *} p<0.05 ;{ }^{* * *} p<0.10$

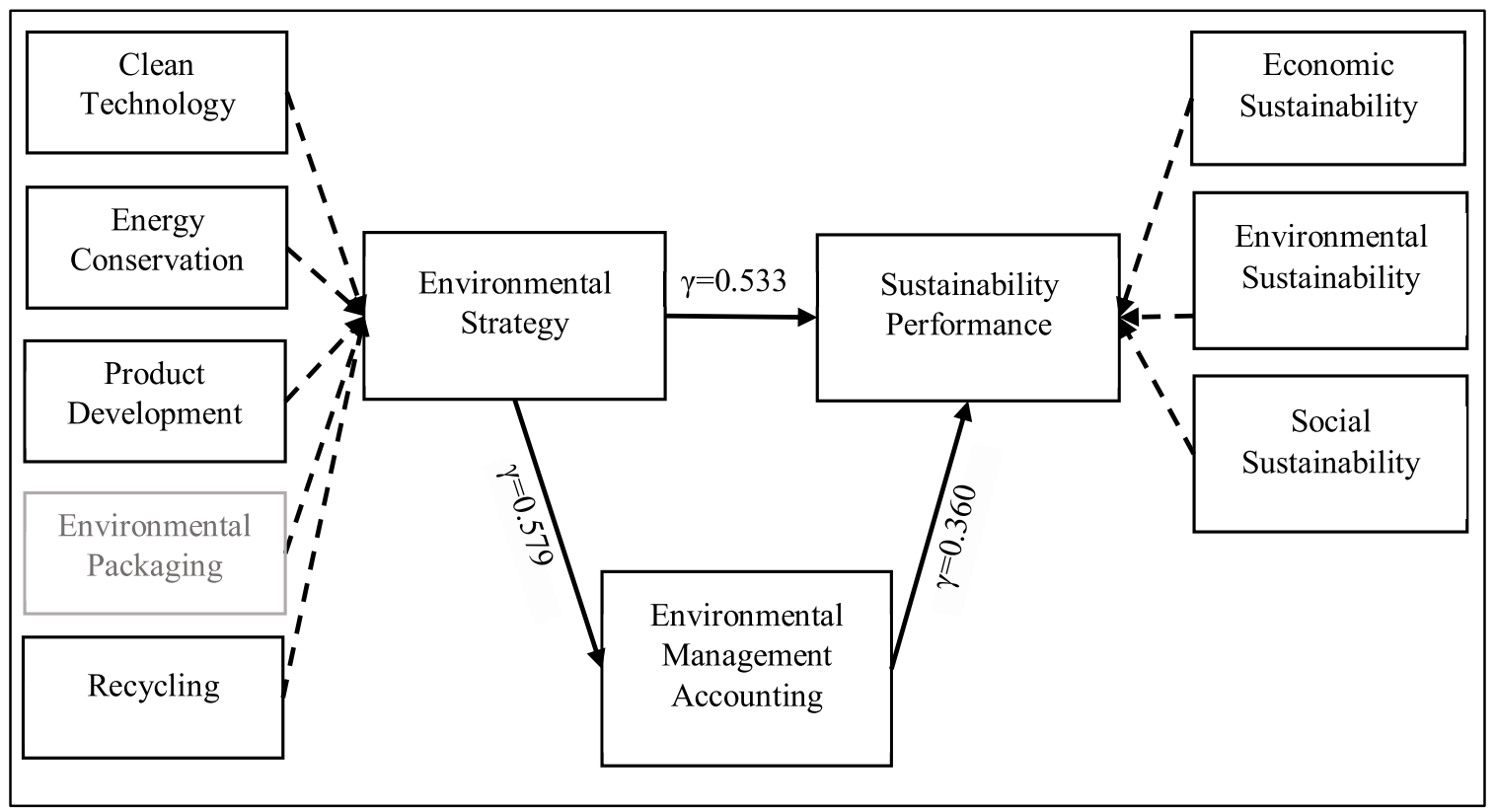

Figure 3: Revised Model 
According to the statistics in Figure 3, the environmental strategy has a positive and significant effect on sustainability performance factor $(\gamma=0.533$ and $p=0.000$ ). The change in the gamma value was $\Delta \gamma=0.024$ according to the result of the previous analysis $(\gamma=0.509$ and $p=0.000)$. This change confirms that the revised model is structurally more meaningful and achieves high effectiveness. Therefore, the structural relationship stated in Hypothesis 1 has been statistically verified and accepted. As shown in Table 6, the change in the variance value has become $\Delta R^{2}=2 \%$. With the revision of the model, the scientific significance was increased and the effect of the independent variable on the dependent variable increased. The statistical value of the correlation expressed in hypothesis 2 has reached a higher significance by revising the model. According to the analysis performed in the previous step, gamma value and significance were determined as $\gamma=0360$ and $p=0.000$. The results in the second stage test results show that the difference in the gamma value is $\Delta y=0.004$. With the elimination of weak parameters in the model, the level of expression power and meaningfulness of the model increased. In this context Hypothesis, 2 is accepted according to the structural model results. Environmental management accounting has a significant impact on sustainability performance. At the variance level, there is a positive change in the $\Delta R^{2}=1 \%$ scale. The environmental strategy variable $\rightarrow$ environmental management accounting relation became more meaningful and the model coefficient reached from $\gamma=0.554$ level to $\gamma=0.579$ level. Hypothesis 3 is accepted in this context. These results are consistent with the findings of previous studies (Aragon-Correa et al., 2008; Christ and Burritt, 2013; Journeault, 2016; Pondeville et al., 2013; Solovida and Latan, 2017). Hypothesis 4 , in which the joint effects of the predictor variables on the dependent variable were evaluated, was found to be significant according to the revised model results $(\gamma=0.646$ and $p=0.000)$. The change in the revised model coefficient showed an increase in $\Delta \gamma=0.028$ compared to the previous step. The variance change detected in this step is measured as $\Delta R^{2}=4 \%$. The compliance indices of the model confirmed the validity of the theoretical model. Wagner and Schaltegger, 2004). Whether a research model is made up of correct variables and whether the model is theoretically correctly designed or not (Goodness Fit Index) shows that the research model has good structural fit with respect to the values in Table 6 (GFI=0.98).

Table 6: Revised Test Results

\begin{tabular}{lccccccc}
\hline \multicolumn{1}{c}{ Paths } & $\mathrm{Y}$ & $\mathrm{R}^{2}(\%)$ & $\Delta \mathrm{R}^{2}$ & $\mathrm{p}$ & $\mathrm{X}^{2} / \mathrm{df}$ & $\mathrm{RMSEA}$ & $\mathrm{GFI}$ \\
\hline EST $\rightarrow$ SUP & 0.533 & 41 & 2 & $0.000^{*}$ & 2.02 & 0.02 & 0.95 \\
EMA $\rightarrow$ SUP & 0.366 & 31 & 1 & $0.000^{*}$ & 2.21 & 0.02 & 0.95 \\
EST $\rightarrow$ EMA & 0.579 & 53 & 2 & $0.000^{*}$ & 1.98 & 0.03 & 0.96 \\
EST $x$ EMA $\rightarrow$ SUP & 0.646 & 63 & 4 & $0.000^{*}$ & 1.60 & 0.01 & 0.98 \\
\hline
\end{tabular}

EST: Environmental Strategy; SUP: Sustainability Performance; EMA: Environmental Management Accounting ${ }^{*} p<0.01 ;{ }^{* *} p<0.05 ;{ }^{* *} p<0.10$

Table 7 shows the statistical findings of the structural model, which were derived by retesting weak values and correlating sub-factors.

Table 7: Relations Between Sub Factors (Revised)

\begin{tabular}{lllllll}
\hline & \multicolumn{2}{c}{$\begin{array}{c}\text { Economical } \\
\text { Sustainability }\end{array}$} & $\begin{array}{c}\text { Environmental } \\
\text { Sustainability }\end{array}$ & \multicolumn{2}{c}{ Social Sustainability } \\
\hline Clean Technology & $\beta$ & $p$ & $\beta$ & $p$ & $\beta$ & $p$ \\
Energy Conservation & $0.140^{* * *}$ & 0.027 & $0.168^{* *}$ & 0.020 & $0.151^{* *}$ & 0.020 \\
Product Development & 0.059 & 0.104 & $0.133^{* *}$ & 0.037 & $0.081^{* * *}$ & 0.085 \\
Env. Packaging & $0.133^{* *}$ & 0.033 & $0.074^{* * *}$ & 0.099 & 0.069 & 0.109 \\
Recycling & Extracted & Extracted & Extracted & Extracted & Extracted & Extracted \\
Environmental Management Accounting & $0.146^{* *}$ & 0.020 & $0.193^{*}$ & 0.008 & $0.108^{* * *}$ & 0.067 \\
\hline
\end{tabular}

${ }^{*} p<0.01 ;{ }^{* *} p<0.05 ;{ }^{* * *} p<0.10$ 
The revised test scores in Table 7 show that the variable with the highest effect on the economic sustainability sub-factor is recycling $(\beta=0.146)$. For environmental sustainability, recycling is leading. The most effective factor for social sustainability is the clean technology strategy. The mediator effect of the environmental management accounting factor in the model was also investigated in order to contribute to the scientific perspective of the study while not being the main target of the study. The values showing the effect of the intermediate variable are given in Table 8.

Table 8: The Mediator Effect of Environmental Management Accounting

\begin{tabular}{lccc}
\hline Test & Z-Value & Std. Error & $\mathrm{p}$ \\
\hline Aroian Test & 3.376 & 0.0039 & $0.002^{*}$ \\
Goodman Test & 3.388 & 0.0117 & $0.004^{*}$ \\
\hline
\end{tabular}

${ }^{*} \mathrm{p}<0.01 ;{ }^{* *} \mathrm{p}<0.05 ;{ }^{* * *} \mathrm{p}<0.10$

Environmental Management Accounting is influencing the effect of environmental strategy on sustainability performance as an intermediate variable. Both Aroian test results (Std.Error $=0.0398$ and $p=0.002$ ) and Goodman test results (Std.Error $=0.0117$ and $p=0.004$ ), environmental management accounting factor with environmental strategy and sustainability performance is a factor with mediator effect.

\section{DISCUSSION and CONCLUSION}

The study aims to determine the direct and joint effects of environmental strategies on sustainability performance under environmental management accounting. The environmental management accounting refers to accounting processes that help the enterprise plan and control and evaluate environmental, economic and social activities in an accurate and efficient manner. This study presents the following results and contributions based on data from production organizations operating in different sectors in Istanbul.

As hypothesized, the study finds that sustainable performance is a major part of sustainability development. Environmental strategies are positively affecting the environmental, economic and social sustainability of enterprises through the valuable knowledge and policies they contain. According to the standardized coefficient of structural pats, the intensity of this effect is $\gamma: 0.553$. The finding is consistent with Eiadat et al. (2008) and Wijethilake et al. (2016). It has been stated that management control systems are an effective factor in improving the performance of the organizations.

The environmental management accounting techniques and tools affect firms' both financial and non-financial performance significantly in a positive direction ( $\gamma: 0.366)$. The improvement in the effectiveness and development of the environmental management accounting system will increase the sustainability performance of the business. Alewine and Stone (2013) found that environmental management accountability has affected the ability of businesses to invest and decision-making processes. The findings of this research consistent with Hart and Dowell (2011). Direct observation of this effect is technically comprehensive and requires a long-term evaluation. Managers and accounting practitioners should increase the inclusion of the environmental management accounting system within the firm. Implementing environmental management accounting should not be regarded as an act of the accounting department alone. Finance, research and development, human resources departments should be included in the qualitative and quantitative development of sustainability performance.

According to revised results in the structural equation model, the high level of the gamma coefficient of environmental strategies and the joint effect of environmental management accounting system factors on sustainability performance makes these two factors important for company success. While not being the main aim of the study, the existence of a meaningful linkage has been examined when environmental management accounting is the intermediate variable. Aroian, and Goodman tests were found to have an intermediate effect on environmental management accounting. This result shows that, with the adaptation of environmental management accounting of a production company, the efficiency of environmental strategies and sustainability performance will increase.

Several suggestions may be developed for executives, stakeholders, and researchers in direction of findings. Environmental strategies are sometimes overlooked and not sufficiently taken into consideration by firms. The development and implementation of environmental strategies is a difficult process. However, significant and effective results on qualitative and quantitative performance are brought to the fore. Implementation of cost strategies and environmental strategies have not been avoided. Modern technology, energy conservation strategy, recycling strategy or environmentally friendly production and marketing 
(innovation) strategies businesses in today's market conditions where customer demands are more sensitive to environmentally sensitive products and technologies will respond to anticipation.

Another contribution of this study to the literature is to develop a new and original environmental strategy scale based on the environmental strategies set out in Parker (1997). This scale provides a very useful measurement and evaluation tool for future studies. In this study, the sample size is very limited due to the limited cost and accessibility possibilities. However, there is a need for large sample work, as opposed to the possibility that the losses of the producers can be given to the environment because of their activities and that they are higher than those of the service sector. To find more inclusive and meaningful results, researchers can carry out studies on larger and/or non-production sectors in future studies. 


\section{References}

Abdul-Rashid SH, Sakundarini N, Ghazilla R.A.R. and Thurasamy R. (2017), The impact of sustainable manufacturing practices on sustainability performance: Empirical evidence from Malaysia, International Journal Operational Production Management, 37,182-204.

Adams, A.C., Muir, S. and Hoque, Z. (2014), Measurement of sustainability performance in the public sector. Sustainability Accounting, Management Policy Journal, 5, 46-67.

Adams, C. A. and McNicholas, P. (2007). Making a difference: sustainability reporting, accountability and organizational change. Accounting, Auditing \& Accountability Journal, 20(3), 382-402.

Albelda, E. (2011), The role of management accounting practices as facilitators of the environmental management", Sustainability, Accounting, Management and Policy Journal, 2(1), 76-100.

Alewine, H.C. and Stone, D.N. (2013). How does environmental accounting information influence attention and investment? International Journal of Accounting \& Information Management, 21(1), 22-52.

Alewine, H.C. (2010), A model for conducting experimental environmental accounting research", Sustainability Accounting, Management and Policy Journal, 1(2), 256-291.

Alt, E., Diez-de-Castro, E. and Llorens-Montes, F. (2015). Linking employee stakeholders to environmental performance: The role of proactive environmental strategies and shared vision, Journal of Business Ethics, 128(1), 167-181.

Aragon-Correa, J.A., Hurtado-Torres, N., Sharma, S. and Garcia-Morales, V.J. (2008), Environmental strategy and performance in small firms: resource-based perspective, Journal of Environmental Management, 86(1), 88-103.

Aragon-Correa, J.A. and Rubio-Lopez, E.A. (2007) Proactive corporate environmental strategies: Myths and misunderstandings. Long Range Planning, 40, 357-381

Arjali's, D.L. and Mundy, J. (2013). The use of management control systems to manage CSR strategy: a levers of control perspective. Management Accounting Research, 24 (4), 284-300.

Ball, A. (2005), Environmental accounting and change in UK local government, Accounting, Auditing \& Accountability Journal, 18(3), 346-373.
Bansal, P. and Roth, K. (2000), Why companies go green: a model of ecological responsiveness, Academy of Management Journal, 43(4), 717-736.

Bansal, P. (2005), Evolving sustainability: a longitudinal study of corporate sustainable development, Strategic Management Journal, 26 (3), 197-218.

Bartolomeo, M., Bennet, M., Bouma, J., Heydkamp, P., James, P. and Wolters, T. (2000), Environmental Management Accounting in Europe: Current Practice and Future Potential, The European Accounting Review, 9 (1), 31-52.

Bebbington, J. and Gray, R. H. (2001), An account of sustainability: Failure, success and a reconceptualization, Critical Perspectives on Accounting, 12, 557-588.

Bhupendra, K. V. and Sangle, S. (2015). What drives successful implementation of pollution prevention and cleaner technology strategy? The role of innovative capability, Journal of Environmental Management, 155, 184-192.

Bouten, L. and Hoozee, S. (2013) On the interplay between environmental reporting and management accounting change, Management Accounting Research, 24 (4), 333-348

Brown, J. (2009), Democracy, sustainability and dialogic accounting technologies: taking pluralism seriously, Critical Perspectives on Accounting, 20(3), 313-334.

Brundtland, G.H. (1987), Our Common Future: Report of the World Commission on Environment and Development, Oxford University Press

Burritt, R.L. (2012), Environmental performance accountability: planet, people, profits. Accounting, Auditing \& Accountability Journal, 25, 370-405.

Burritt, R.L., Schaltegger, S. and Zvezdov,D. (2011). Carbon management accounting: explaining practice in leading German companies. Australian Accounting Review, 21, 80-98.

Caiado, R.G.G., Quelhas, O.L.G., Nascimento,D.L.M., Anholon, R. and Filho, W.L. (2018) Measurement of sustainability performance in Brazilian organizations, International Journal of Sustainable Development \& World Ecology, 25(4), 312-326

Chenhall, R. H. (2003), Management control systems design within its organizational context: Findings from contingency-based research and directions for the future, Accounting, Organizations and Society, $28,127-168$ 
Christ, K. L. and Burritt, R. L. (2013). Environmental management accounting: the significance of contingent variables for adoption. Journal of Cleaner Production, 41, 163-173.

Claver-Cortés, E., Molina-Azorín, J.F., Pereira-Moliner, J. and López-Gamero, M.D. (2007), Environmental strategies and their impact on hotel performance, Journal of Sustainable Tourism, 15, 663-679.

Clemens, B.N. and Bakstran, L. (2010), A framework of theoretical lenses and strategic purposes to describe relationships among firm environmental strategy, financial performance, and environmental performance, Management Research Review, 33 (4), 393-405,

Comoglio, C. and Botta, S. (2012). The use of indicators and the role of environmental management systems for environmental performances improvement: a survey on ISO 14001 certified companies in the automotive sector, Journal of Cleaner Production, 26(1), 92-102.

Cullen, D. and Whelan, C. (2006), Environmental Management Accounting: The State of Play, Journal of Business \& Economic Re-search, 4(10), 1-6.

Dascalu, C., Caraiani, C., Lungu, C.I., Colceag, F. and Guse, G.R. (2010), The externalities in social environmental accounting, International Journal of Accounting and Information Management, 18(1), 19-30.

De Villiers, C. and Van Staden, C.J. (2006). Can less environmental disclosure have a legitimising effect? Evidence from Africa. Accounting, Organizations and Society, 31, 763-781.

Debnath, S. and Accountants, C. (2012), Environmental management accounting: an overview of its methodological development, International Journal of Business Insights \& Transformation, 5(1), 44-57.

Deegan, C. (2002), Introduction: the legitimising effect of social and environmental disclosures - a theoretical foundation, Accounting, Auditing \& Accountability Journal, 15(3), 282-311.

Delai I. and Takahashi, S. (2011). Sustainability measurement system: a reference model proposal. Social Responsibility Journal, 7, 438-471.

Derchi, G.B., Burkert, M. and Oyon, D. (2015), Environmental management accounting systems: a review of the evidence and propositions for future research, in Epstein, M. and Ferrell, A.M. (Eds), Accounting and Control for Sustainability, Emerald Group Publishing Limited, Bingley, 197-229

Eiadat, Y.; Kelly, A.; Roche, F.; Eyadat, H. (2008), Green and competitive? An empirical test of the mediating role of environmental innovation strategy, Journal of World Business, 43, 131-145.

Elkington, J. (2004). Enter the Triple Bottom Line. In A. Henriques, \& J. Richardson (Eds.), The Triple Bottom Line: Does It All Add Up? London: Earthscan.

Elkington, J. (1998), Cannibals with Forks: The Triple Bottom Line of 21st Century Business; New Society Publishers: Gabriola, BC, Canada.

Epstein, M. and Buhovac, R. (2010). Solving the sustainability implementation challenge, Organisational Dynamics, 39(4), 306-315.

Epstein, M. and Widener, S. (2011). Identification and use of sustainability performance measures in decision making. The Journal of Corporate Citizenship, 40(Winter), 43-73.

Etzion, D. (2007). Research on organizations and the natural environment,1992-present: a review. Journal of Management, 33(4), 637- 664.

Ferreira, A., Moulang, C. and Hendro, B. (2010). Environmental management accounting and innovation: an exploratory analysis. Accounting, Auditing \& Accountability Journal, 23, 920-948.

Figge, F. and Hahn, T. (2013). Value drivers of corporate eco-efficiency: Management accounting information for the efficient use of environmental resources, Management Accounting Research, 24(4), 387-400.

Figge, F., Hahn, T., Schaltegger, S., and Wagner, M. (2002). The sustainability balanced scorecard-Linking sustainability management to business strategy. Business Strategy and the Environment, 11, 269-284.

Fiksel, J., Mcdaniel, J. and Mendenhall, C. (1999). Measuring progress towards sustainability principles. Process and Best Practices. Ohio: Battelle Memorial Institute.

Gale, R. (2006), Environmental costs at a Canadian paper mill: a case study of environmental management accounting (EMA), Journal of Cleaner Production, 14(14), 1237-1251.

Gond, J.P., Cabantous,L. and Krikorian, F. (2017) How do things become strategic? 'Strategifying' corporate social responsibility Strategic Organization, DOI: 10.1177/1476127017702819

Gray, R. H. and Milne, M. J. (2002). Sustainability reporting: Who's kidding whom? Chartered Accountants Journal of New Zealand, 81, 66-70

Gunarathne, N. and Lee, K.H. (2015), Environmental management accounting (EMA) for environmental management and organizational change, Journal of Accounting \& Organizational Change, 11(3), 362-383. 
Hair, J., Black,W., Babin, B., .Anderson, R. and Tatham, R. (2006). Multivariate Data Analysis, Pearson Education, Upper Saddle River, NJ.

Hansen, D.R. and Mowen, M.M. (2005), Environmental Cost Management, Management Accounting, Thomson-South-Western, Mason, $\mathrm{OH}, 490-526$.

Hart, S. L. and Dowell, G. (2011). A natural-resource-based view of the firm: Fifteen years after. Journal of Management, 37(5), 1464-1479.

Hart, S.L. (1995). A natural-resource-based view of the firm. Academy of Management Review, 20(4), 986- 1014.

Haugh, H.M. and Talwar, A. (2010). How do corporations embed sustainability across the organization? Academy Management Learning Education, 9 (3), 384-396.

Henri, J. F. and Journeault, M. (2010). Eco-control: The influence of MCS on environmental and economic performance. Accounting Organizations and Society, 35(1), 63-80.

Herbohn, K. (2005). A full cost environmental accounting experiment. Accounting, Organizations and Society, 30, 519-536.

Hines, R. (1991). On valuing nature. Accounting, Auditing and Accountability Journal, 4(3), 27-29.

Hopwood, A. (2009). Accounting and the environment. Accounting, Organizations and Society, 34(3-4), 433439.

IFAC (2005). International Guidance Document: EMA. International Federation of Accountants, New York.

Ismail, K. and Isa, C.R. (2011), The role of management accounting systems in advanced manufacturing environment, Australian Journal of Basic and Applied Sciences, 5(9), 2196-2209

Journeault, M. (2016), The influence of the eco-control package on environmental and economic performance: a natural resource-based approach, Journal ofManagement Accounting Research, 28(2), 149-178.

Klassen, R.D. and Whybark, D.C. (1999). The impact of environmental technologies on manufacturing performance. Academy of Management Journal, 42, 599-615.

Klassen, R.D. and McLaughlin, C.P. (1996), The impact of environmental management of firm performance, Management Science, 42(8), 1199-1214.

Kocmanová A, Pavláková-Dočekalová M, Škapa,S. and Smolíková,L. (2016), Measuring corporate sustainability and environmental, social, and corporate governance value added. Sustainability. 8, 945.
Labuschagne, C., Brent, A.C. and Van Erck, R.P. (2005), Assessing the sustainability performances of industries. Journal of Cleaner Production, 13 (4), 373-385

Lamberton, G. (2005), Sustainable sufficiency - an internally consistent version of sustainability, Sustainable Development, 13(1), 53-78.

Larrinaga-Gonzalez, C., Carrasco-Fenech, F., Caro-Gonzalez, F. J., Correa-Ruiz, C., and Paez-Sandubete, J. M. (2001). The role of environmental accounting in organizational change: an exploration of Spanish companies. Accounting, Auditing \& Accountability Journal, 14(2), 213239.

Larrinaga-Gonzalez, C. and Bebbington, J. (2001), Accounting change or institutional appropriation? A case study of the implementation of environmental accounting, Critical Perspectives on Accounting, 12(3), 269-292.

Lewis, G. J. and Harvey, B. (2001). Perceived Environmental Uncertainty: The Extension of Miller's Scale to the Natural Environment. Journal of Management Studies, 38, 201-233.

Linnenluecke, M.K. and Griffiths, A. (2013). Firms and sustainability: mapping the intellectual origins and structure of the corporate sustainability field. Global Environmental Change. 23 (1), 382-391

Lodhia, S. and Hess, N. (2014). Sustainability accounting and reporting in the mining industry: current literature and directions for future research. Journal of Cleaner Production, 84, 43-50.

Lozano R. (2015). A holistic perspective on corporate sustainability drivers. Corporate Soc Responsibility Environmental Management, 22, 32-44.

Luzzini D, Brandon-Jones $E$, Brandon-Jones $A$ and Spina G. (2015). From sustainability commitment to performance: the role of intra- and inter-firm collaborative capabilities in the upstream supply chain. International Journal Production Economy, $165,51-63$.

Maas, K., Schaltegger S. and Crutzen, N. (2016). Integrating corporate sustainability assessment, management accounting, control, and reporting. Journal of Cleaner Production. 136, 237-248.

Mákelá, M. (2017). Trends in environmental performance reporting in the Finnish forest industry. Journal of Cleaner Production, 142, 1333-1346.

Mathews, M. R. (1997). Twenty-five years of social and environmental accounting research: Is there a silver jubilee to celebrate? Accounting Auditing and Accountability Journal, 10(2), 481-531. 
Maunders, K.T., and Burritt, L.R. (1991) Accounting and Ecological Crisis, Accounting, Auditing \& Accountability Journal, 4(3), DOI:10.1108/09513579110003277

Mokhtar, N., Jusoh, R. and Zulki, N. (2016), Corporate characteristics and environmental management accounting (EMA) implemen-tation: evidence from Malaysian public listed companies (PLCs), Journal of Cleaner Production, 136, 111-122.

Morioka, S.N. and Carvalho, M.M. (2014). Measuring sustainability in practice: exploring the inclusion of sustainability into corporate performance systems in Brazilian case studies. Journal of Cleaner Production, 136, 123-133.

Owen, D. (2008). Chronicles of wasted time? A personal reflection on the current state of, and future prospects for, social and environmental accounting research. Accounting, Auditing \& Accountability Journal, 21(2), 240-267.

Parker, L.D. (1997), Accounting for Environmental Strategy: Cost Management, Control and Performance Evaluation, Asia-Pacific Journal of Accounting, 4(2), 145-173.

Passetti, E., Cinquini, L., Marelli, A. and Tenucci, A. (2014). Sustainability accounting in action: lights and shadows in the Italian context. British Accounting Review, 46, 295-308.

Perego, P. and Hartmann, F. (2009), Aligning performance measurement systems with strategy: the case of environmental strategy, Abacus, 45(4), 397-428.

Pérez, E.A., Ruiz, C.C. and Fenech, F.C. (2007), Environmental management systems as an embedding mechanism: a research note, Accounting, Auditing \&Accountability Journal, 20(3), 403-422.

Pondeville, S., Swaen, V. and Ronge, Y. D. (2013). Environmental management control systems: the role of contextual and strategic factors. Management Accounting Research, 24, 317-332.

Roca, L.C. and Searcy, C. (2012). An analysis of indicators disclosed in corporate sustainability reports. Journal of Cleaner Production, 20, 103-118.

Rodrigue, M., Magnan, M. and Boulianne, E. (2013). Stakeholders' influence on environmental strategy and performance indicators: a managerial perspective. Management Accounting Research, 24,301-316.

Russo, M. V. and Fouts, P. A. (1997). A resource-based perspective on corporate environmental performance and profitability. Academy of Management Journal, 40(3), 534-559.
Schaltegger, S. and Burritt, R.L. (2000), Contemporary Environmental Accounting: Issues, Concepts and Practice, Greenleaf Publishing, Sheffield.

Schaltegger, S. and Csutora, M. (2012). Carbon accounting for sustainability and management. Status quo and challenges. Journal of Cleaner Production, 36, 1-16.

Schrettle S, Hinz A, Scherrer-Rathje M, and Friedli T. (2014). Turning sustainability into action: explaining firms' sustainability efforts and their impact on firm performance. International Journal of Production Economy, 147, 73-84.

Sharma, S. (2014). Competing for a sustainable world: Building capacity for sustainable innovation. Sheffield: Greenleaf Publishing.

Shields, D. and Boer, G. (1997), Research in environmental accounting, Journal of Accounting \& Public Policy, $16(2), 117-23$

Silvestre, W.J., Antunes, P., Amaro, A. and Leal Filho W. (2015). Assessment of corporate sustainability: study of hybrid relations using Hybrid Bottom Line model. International of Sustainable Development \&World Ecology. 37-41.

Silvestre, W.J., Antunes. P. and Leal Filho W. (2016). The corporate sustainability typology: analysing sustainability drivers and fostering sustainability at enterprises. Technological and Economic Development of Economy, 24(2), 1-21

Solovida, G.T. and Latan, H. (2017), Linking environmental strategy to environmental performance: Mediation role of environmental management accounting, Sustainability Accounting, Management and Policy Journal, 8(5), 595-619.

Spence, C., Husillos, J. and Correa-Ruiz, C. (2010). Cargo cult science and the death of politics: a critical review of social and environmental accounting research. Critical Perspectives on Accounting, 21(1), 76-89.

Spence, L.J. and Rinaldi, L. (2014). Governmentality in accounting and accountability: a case study of embedding sustainability in a supply chain. Accounting, Organizations and Society, 39, 433-452.

Thomson, I. (2007). Mapping the terrain of sustainability accounting. In: Unerman, J., Bebbington, J., O'Dwyer, B.(Eds.), Sustainability Accounting and Accountability, Routledge.

Tinker, T. and Gray, R. (2003) Beyond a critique of pure reason: From policy to politics to praxis in environmental and social research, Accounting, Auditing \& Accountability Journal, 16(5), 727-761 
Tregidga, H., Milne, M. and Kearins, K. (2014). (Re) presenting 'sustainable organizations'. Accounting, Organizations and Society, 39, 477-494.

Wagner, M. and Schaltegger, S. (2003), How does sustainability performance relate to business competitiveness?, Greener Management International, 44, 5-16.

Wagner, M. and Schaltegger, S. (2004). The effect of corporate environmental strategy choice and environmental performance on competitiveness and economic performance: an empirical study of EU manufacturing. European Management Journal, 22 (5), 557-572.

Wijethilake, C., Munir, R. and Appuham, R. (2016) Environmental Innovation strategy and organizational performance: enabling and controlling uses of management control systems, Journal of Business Ethics, (in press)

Wilmshurst, T.D. and Frost, G.R. (2001). The role of accounting and the accountant in the environmental management system. Business Strategy and the Environment, 10(3), 135-147.

$\mathrm{Wu}$, Z. and Pagell M. (2011). Balancing priorities: decision-making in sustainable supply chain management. Journal of Operations Management, 29(6), 577-590.

Yongvanich, K., and Guthrie, J. (2006). An extended performance reporting framework for social and environmental accounting. Business Strategy and the Environment, 15(5), 309-321. 
Annex 1. Survey

Dear participant,

The research conducting aims to explain the relationship between environmental strategies and sustainability performance in the context of sustainability accounting. Your response will be protected as private and used for scientific objectives.

Best regards,

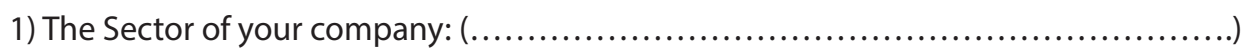

2) Number of employees: (.....................................................)

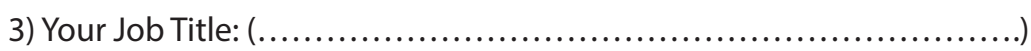

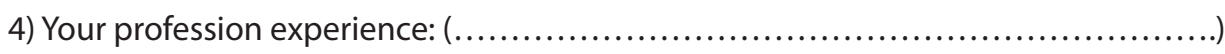

Taking into account the activities of your company indicate your opinion about the

following statements.

*1- Fully Disagree 2-Partially Disagree 3-Neutral 4- Partially Agree 5-Fully Agree

\section{Environmental Strategies}

1) Clean Technology Usage Strategy

Our business is intended to use practices and technologies that are less harmful to the environment in their operational processes

Operational processes use technologies with a low risk of harm to the environment

Carbon emissions and waste generation are the priorities of our use of low technology.

2) Energy Conservation Strategy

Reduction of energy consumption in operational processes is aimed to operate.

Energy alternatives towards environmental protection are used in our preference.

Reducing energy costs is ahead of our company

3) Environmentally Friendly Product Development and Marketing Strategy

It is our primary purpose to operate environmental awareness in product development and marketing.

We design our products to minimize damage to the environment.

In the production of our products, it is our priority to use less harmful raw materials and components.

4) Environmental Packaging Strategy

In the packaging of our products, we use reminders and signs to protect the environment and protect the environment.

Product packages are made from low-risk materials for environmental damage.

The product packaging is prepared from non-toxic materials.

5) Recycling Strategy

Our products are prepared from recyclable raw materials.

Recycling is a priority policy in the work of the enterprise.

Using organic and recyclable raw materials is the main objective of our company.

\section{Environmental Management Accounting}

The company takes into account environment-related costs

The company estimates environment-related contingent liabilities

The company does a classification of environment-related costs

The company allocates environment-related costs to production processes

The company allocates environment-related costs to products

The company supports activities for improvement to environment-related cost management

The company makes and uses environment-related cost accounts

The company uses environment-related key performance indicators

The company does product inventory analysis

The company does product impact analysis

The company uses product improvement analysis

The company uses product life cycle cost assessments 


\section{Sustainability Performance}

1) Economical Sustainability

Cost performance is improving positively.

Environmental and social performance has improved positively.

Quality management has been implemented successfully

Labor practice indicators were achieved at the targeted level.

Customer satisfaction is the targeted level

Corporate reputation is the targeted level.

It is suited to the objectives of the HUM capital development operator.

2) Social Sustainability

Inter-firm collaborative capabilities are in line with targets.

Intra-firm collaborative capabilities suited to business goals

Employee satisfaction is targeted.

Supplier relations continued in line with business interests.

Balancing professional and family life has been emphasized by business management.

Transparency in information has been adequately provided by the reports.

Representation and dialogue with employees have been held regularly.

Code of conduct is implemented in operation.

Corporate governance is the targeted level.

Support of social setting is suitable for the targets.

The sustainable working condition is provided to stakeholders in business management.

3) Environmental Sustainability

Environmental protection has been considered in operational processes.

Green marketing applications have been made.

Environmental policy has been applied meticulously.

Energy conservation has achieved the targets.

Carbon footprint reduction is provided.

Reduction in the amount of energy used.

Reduction of air pollution is provided.

Waste management was done at level enough

Reduction in the amount of resource has been used.

Sources of recyclable raw material are used. 